\title{
Nuclear Material Accounting and Reporting Information Systems: Capabilities Review
}

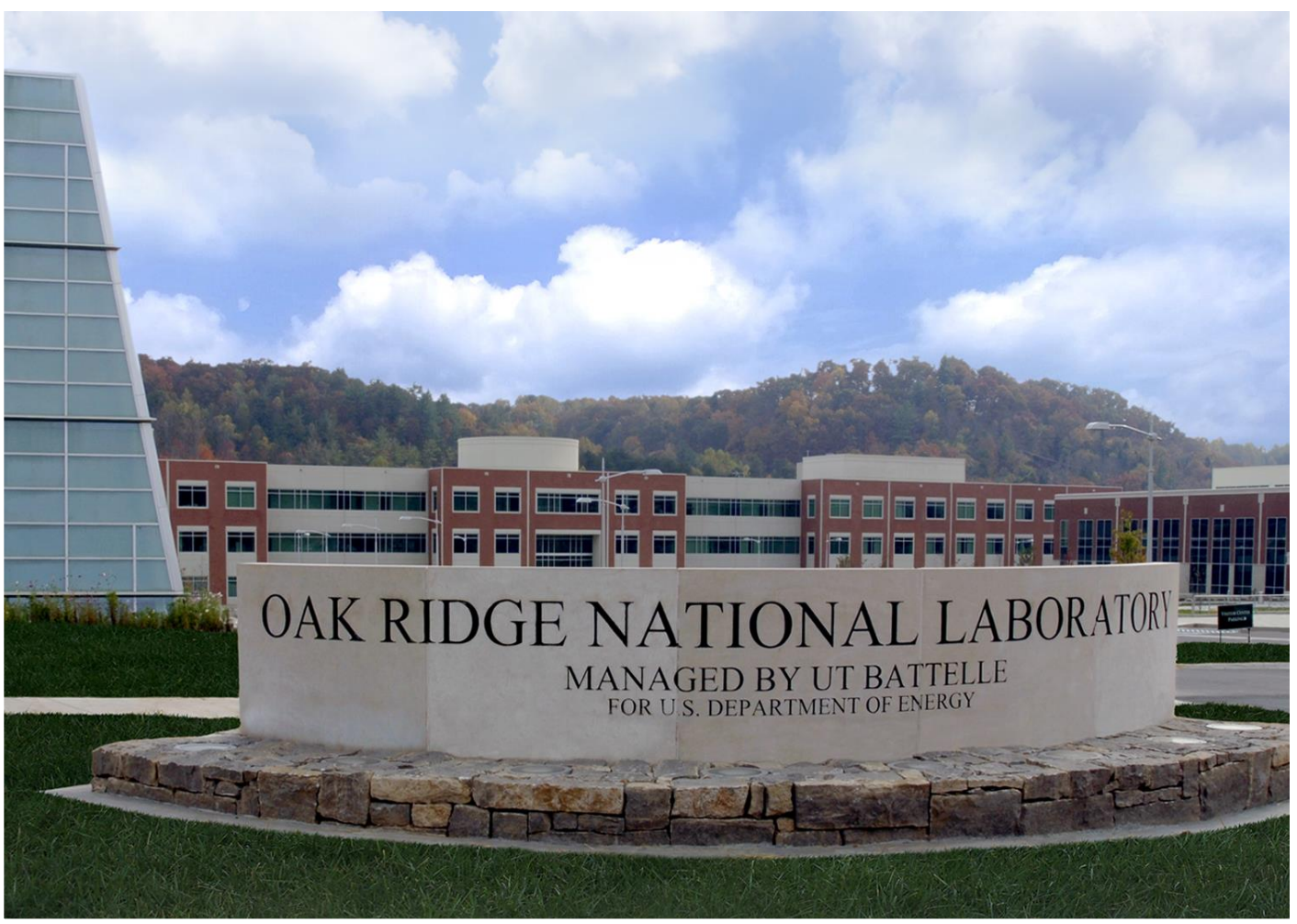

Approved for public release. Distribution is unlimited.
John Oakberg

Kimberly Gilligan

September 2014 


\section{DOCUMENT AVAILABILITY}

Reports produced after January 1, 1996, are generally available free via US Department of Energy (DOE) SciTech Connect.

Website http://www.osti.gov/scitech/

Reports produced before January 1, 1996, may be purchased by members of the public from the following source:

National Technical Information Service

5285 Port Royal Road

Springfield, VA 22161

Telephone 703-605-6000 (1-800-553-6847)

TDD 703-487-4639

Fax 703-605-6900

E-mail info@ntis.gov

Website http://www.ntis.gov/help/ordermethods.aspx

Reports are available to DOE employees, DOE contractors, Energy Technology Data Exchange representatives, and International Nuclear Information System representatives from the following source:

Office of Scientific and Technical Information

PO Box 62

Oak Ridge, TN 37831

Telephone 865-576-8401

Fax 865-576-5728

E-mail reports@osti.gov

Website http://www.osti.gov/contact.html

This report was prepared as an account of work sponsored by an agency of the United States Government. Neither the United States Government nor any agency thereof, nor any of their employees, makes any warranty, express or implied, or assumes any legal liability or responsibility for the accuracy, completeness, or usefulness of any information, apparatus, product, or process disclosed, or represents that its use would not infringe privately owned rights. Reference herein to any specific commercial product, process, or service by trade name, trademark, manufacturer, or otherwise, does not necessarily constitute or imply its endorsement, recommendation, or favoring by the United States Government or any agency thereof. The views and opinions of authors expressed herein do not necessarily state or reflect those of the United States Government or any agency thereof. 
Nuclear Security and Isotope Technology Division

\title{
NUCLEAR MATERIAL ACCOUNTING AND REPORTING INFORMATION SYSTEMS: CAPABILITIES REVIEW
}

\author{
John Oakberg* \\ Kimberly Gilligan
}

*Haselwood Services and Manufacturing, Inc., Lenoir City, Tennessee

Date Published: September 2014

\author{
Prepared by \\ OAK RIDGE NATIONAL LABORATORY \\ Oak Ridge, Tennessee 37831-6283 \\ managed by \\ UT-BATTELLE, LLC \\ for the \\ US DEPARTMENT OF ENERGY \\ under contract DE-AC05-00OR22725
}





\section{CONTENTS}

Page

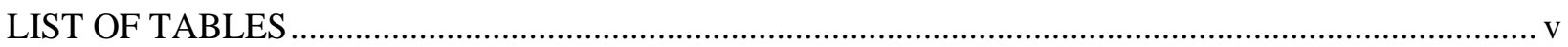

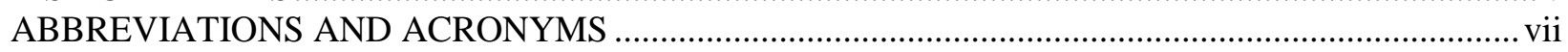

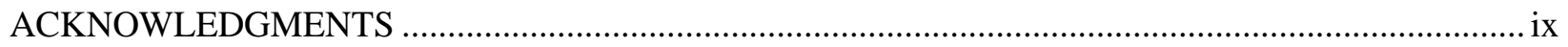

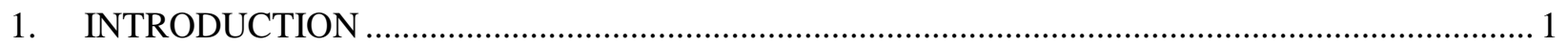

2. SYSTEM CAPABILITIES RELATED TO STATE SAFEGUARDS STATUS ….......................... 2

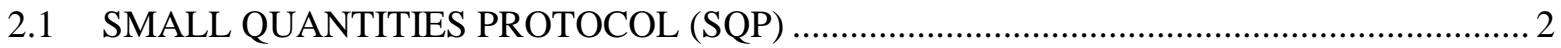

2.2 MODIFIED SMALL QUANTITIES PROTOCOL (Mod SQP) ........................................ 3

2.3 MINING AND MILLING (WITH OR WITHOUT AN SQP) .......................................... 3

2.4 MINIMAL NUCLEAR PROGRAM (AND NOT EXPECTING TO DEVELOP A

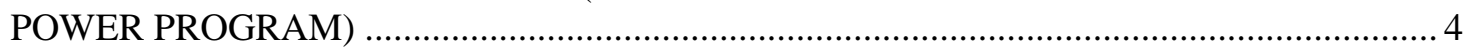

2.5 MINIMAL NUCLEAR PROGRAM (BUT EXPECTING FURTHER

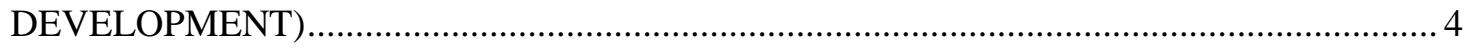

2.6 NUCLEAR POWER PROGRAM WITHOUT OTHER FUEL CYCLE FACILITIES ............ 5

2.7 NUCLEAR POWER PROGRAM WITH OTHER FUEL CYCLE FACILITIES .................... 5

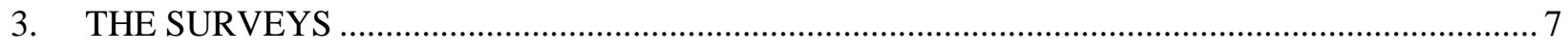

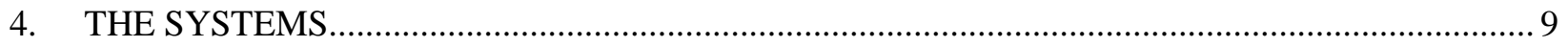

4.1 LOCAL AREA NUCLEAR MATERIAL ACCOUNTABILITY SOFTWARE

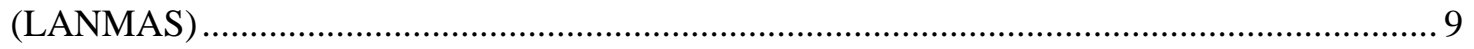

4.2 NUCLEAR ACCOUNTING AND COMPLIANCE (NAC) REPORTER ............................. 9

4.3 SAFEGUARDS TECHNOLOGY FOR ACCOUNTING AND REPORTING (STAR) ......... 10

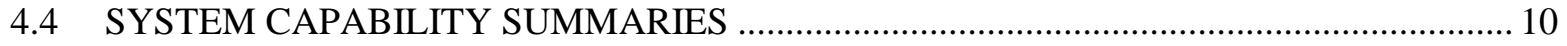

5. RECOMMENDATIONS TO POTENTIAL FUTURE USERS OF THE SYSTEMS ....................... 14

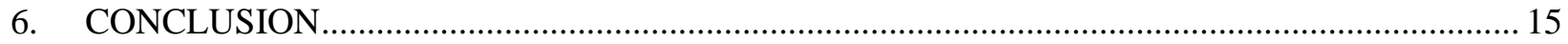

APPENDIX A. SURVEY: INFORMATION SYSTEM CAPABILITY ASSESSMENT STATE-

LEVEL NUCLEAR MATERIAL ACCOUNTING AND REPORTING …................................. A-1 APPENDIX B. SURVEY: INFORMATION SYSTEM CAPABILITY ASSESSMENT FACILITY-

LEVEL NUCLEAR MATERIAL ACCOUNTING AND REPORTING …............................... B-1

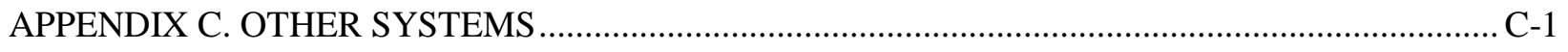





\section{LIST OF TABLES}

\section{Table}

Page

Table 1. State-Level Nuclear Material Accounting and Reporting System Capability Summary.............. 11

Table 2. Facility-Level Nuclear Material Accounting and Reporting System Capability Summary.......... 12

Table 3. Overview of Systems Based on a State's Safeguards Status ...................................................... 14 



\section{ABBREVIATIONS AND ACRONYMS}

AIMAS Automated Inventory Material Accounting System

ANL

Argonne National Laboratory

AP

Additional Protocol

DOE

US Department of Energy

ENMAS

Euratom Nuclear Material Accountancy System

EU

European Union

Euratom

European Atomic Energy Community

FARMS

Facility Records and Reports Model System

FIS

Federal Information System

IAEA

International Atomic Energy Agency

INFCIRC

Information Circular

INSEP

International Nuclear Safeguards Engagement Program

LANMAS

Local Area Nuclear Material Accountability Software

LOF

Locations Outside Facilities

MBA

Material balance area

MCAS

Material Control and Accounting (MC\&A) Computerized Accounting System

Mod SQP

Modified small quantities protocol

MUF

Material unaccounted for

NAC

Nuclear Accounting and Compliance (Reporter)

NMMSS

Nuclear Material Management and Safeguards System

NNSA

National Nuclear Security Administration (DOE)

NPP

Nuclear power plant

RR

Research reactor

SQP

Small quantities protocol

SRNL

Savannah River National Laboratory

SSAC

State system of accounting for and control of nuclear material

STAR

Safeguards Technology for Accounting and Reporting 



\section{ACKNOWLEDGMENTS}

The authors thank the US Department of Energy (DOE) National Nuclear Security Administration (NNSA) Office of Nonproliferation and International Security (NA-24) for the support given to this assessment. In particular, encouragement and approval originally by NA-24's Matt Van Sickle and Chris Behan and later support from NA-24's Margot Mininni, Ike Therios (ANL contractor), and Scott Purvis are greatly appreciated. A special thank you is also due to Amy Whitworth and Carol Raeder of the DOE/NNSA Office of Security Operations and Programmatic Planning (NA-71), and to Geneva Johnson formerly of ORNL — their input was invaluable. 



\section{INTRODUCTION}

A significant aspect of the information management component in the International Nuclear Safeguards Engagement Program (INSEP) is assisting states in obtaining appropriate information systems for the implementation of safeguards.

To achieve that objective, a critical first step is the identification and assessment of available systems for nuclear material accounting and additional protocol information that could be recommended for use in a state. Depending on state requirements and their specific safeguards implementation, there may be needs at the facility, site, and state levels or some combination thereof. There are existing systems that could meet state needs, and only those that would be available for release were evaluated.

For those systems identified as potential candidates for consideration, the objective was to collect pertinent information to permit determining the best match between the needs of facilities, sites, and states with the capabilities of the associated systems. Considerations were made for a range of nuclear programs.

In some states there are compound needs, which imply more complex information systems. On the other end of the spectrum, there are states with minimal nuclear programs and undecided future plans, suggesting a more straightforward information system need. Therefore, even though an information system does not implement a certain advanced capability, that may in fact be a desired feature, especially for a state not needing an extensive system at all levels of the nuclear program.

To collect information about available systems, detailed sets of questions were developed to assist in obtaining specifics about applications that are potential candidates for deployment in a state. Separate lists were prepared for nuclear material accounting information at the state and facility levels. Information collected includes data related to system requirements, documentation, capability to input a range of information types, generate reports, etc. More detail on the type of questions asked and data collected is available in Section 3, The Surveys. Copies of the surveys themselves are available in Appendices A (state level) and B (facility level).

In total, 11 systems were identified. These range from private ventures to government-developed systems. Visits were made to several vendors that had systems that could be made available to INSEP partners. The purpose of these visits was to discuss the survey results and to receive live demonstrations. Seeing a system in operation and actually viewing the capabilities proved to be invaluable in obtaining information and performing the reviews. The source information, which was necessarily detailed, was then assembled into a summarized format to provide an overview for review by individual states. The results of the summarization are in Section 4, The Systems. Appendix C outlines the other systems identified that were not available for in-depth review for the various reasons described.

While there is a demand and real need for nuclear material accounting and reporting information systems, only a select few are commercially available as the market is small. The actual number of systems available for review and consideration is 3 out of the 11 identified. 


\section{SYSTEM CAPABILITIES RELATED TO STATE SAFEGUARDS STATUS}

All states with an INFCIRC/153-type safeguards agreement are required to establish and maintain a state system of accounting for and control of nuclear material (SSAC). The SSAC consists of the procedures and methods for implementing the state's safeguards obligation to account for and control the use and movement of all nuclear material in the state, to monitor imports and exports of nuclear material, to maintain accurate records of nuclear material inventory and transactions, and to prepare and submit detailed and timely reports to the International Atomic Energy Agency (IAEA). It can include various levels of computerized information systems.

There are some capabilities that an information system for nuclear material accounting and reporting must have. Some software capabilities are correlated with specific nuclear fuel cycle stages, while other capabilities would be convenient for a state but are not mandatory. As mentioned elsewhere in this study, there are advanced features that many states do not need. These advanced features could even be a disadvantage by needlessly complicating the implementation.

The following sections include the description, basic requirements, and information system needs of states with differing levels of nuclear fuel cycle implementation and/or plans for development. In addition, it is a good practice for all states to develop and use an information management plan, tailored to their nuclear program.

\subsection{SMALL QUANTITIES PROTOCOL (SQP)}

\section{Description}

Countries with a small quantities protocol (SQP) agreement in addition to their safeguards agreements have little to no nuclear material in their state, and no nuclear material in a facility. All nuclear material in an SQP state is held in locations outside facilities (LOFs). The original SQP holds in abeyance implementation of most safeguards activities in order to minimize the burden on the state. Because these states are not required to submit an initial report and inventory changes to the IAEA, their information system needs are minimal. The lessened burdens are held in place until facilities or the amount of nuclear material in a state meet predetermined conditions.

\section{Basic requirements}

The state is required to annually report all exports and imports of source material for nuclear purposes. If a state only has the mining and milling phase of the nuclear program, it is unlikely to have imports, though that possibility needs to be considered as well. While it is not strictly required to report source material exports to nuclear weapons states for nuclear purposes, it is good practice to report those.

Annual reports to the IAEA of exports and imports of nuclear material are required, and it is good practice to report more often during the year, such as monthly or when transfers occur.

\section{System needs}

The use of a spreadsheet-type system may be sufficient, depending on the number of transactions for the state. 


\subsection{MODIFIED SMALL QUANTITIES PROTOCOL (Mod SQP)}

\section{Description}

Countries with a modified small quantities protocol (Mod SQP) to their safeguards agreement have more reporting requirements than a state with an "original" SQP. They are required to submit an initial report to the IAEA on the inventory amounts and locations of all nuclear material held in LOFs within the state. Subsequently, annual reports of inventory changes are required. The IAEA may perform an inspection to verify the initial report as well as ad hoc and special inspections at later dates. This agreement is held in place until the amount of nuclear material in the state exceeds a predetermined amount or the decision has been made to build a facility.

\section{Basic requirements}

The state is required to report all exports of source materials to non-nuclear weapon states for nuclear purposes. If a state only has the mining and milling phase of the nuclear program, it is unlikely to have imports, though that possibility needs to be considered as well. In addition, even though it is not strictly required to report source material exports to nuclear weapons states for nuclear purposes, it is good practice to report those exports.

Annual reports to the IAEA on inventory changes of nuclear material are required, and it is good practice to report more often during the year, such as monthly or when the changes occur.

\section{System needs}

The use of a spreadsheet-type system may be sufficient, depending on the number of transactions for the State.

It is possible for a state with a Mod SQP to have exempted materials, which need to be accounted for and tracked. In the event an additional protocol (INFCIRC/540) is in place, exempted materials need to also be declared under the provisions of the relevant additional protocol articles and should correspond to the nuclear material accounting records.

\subsection{MINING AND MILLING (WITH OR WITHOUT AN SQP)}

\section{Description}

For a state with primarily mining and milling operations and no facilities under IAEA safeguards, full nuclear material accountancy is not required. However, it still is necessary to track and report imports and exports of source materials (e.g., yellow cake) for nuclear purposes. If an additional protocol is in force, similar efforts are needed for exports and imports for non-nuclear purposes, as well as stocks of material.

Reports of exports and imports of source material for non-nuclear purposes, as well as stocks of source material, are declared under the additional protocol and are outside the general scope of this study. Nevertheless, the process for recording the information is essentially the same, regardless of the end use of the material. Information about mines and their total production and capacity are also covered in a separate article of the additional protocol.

\section{Basic requirements}

The state is required to report all exports of source materials to non-nuclear weapon states for nuclear purposes. If a state only has the mining and milling phase of the nuclear program, it is unlikely to have 
imports, though that possibility needs to be considered as well. Additionally, while a state is not strictly required to report source material exports to nuclear weapons states for nuclear purposes, it is good practice to report those anyway.

\section{System needs}

A records system at the mines and milling facilities is necessary to capture the information and to provide it to a state authority. It is a decision at the state level if the mine/facility will prepare reports in the format for transmission to the IAEA or if that will be done at the state level.

\subsection{MINIMAL NUCLEAR PROGRAM (AND NOT EXPECTING TO DEVELOP A POWER PROGRAM)}

\section{Description}

A state with a minimal nuclear program would have at least one facility under IAEA safeguards, such as a research reactor or critical assembly. There would be no long-term plans or discussions on any additional nuclear activities, such as a power reactor.

\section{Basic requirements}

All relevant paragraphs of INFCIRC/153 will be in force, and the requirements of that document need to be met, as for any facility currently under IAEA safeguards.

\section{System needs}

A records system at the existing facilities is already necessary to capture nuclear material accounting information and to provide it to a state authority, in order to meet safeguards requirements. Since the state is already required to meet safeguards requirements, any new system would need to meet those needs.

\subsection{MINIMAL NUCLEAR PROGRAM (BUT EXPECTING FURTHER DEVELOPMENT)}

\section{Description}

A state with a minimum nuclear program would have at least one facility under IAEA safeguards, such as a research reactor or critical assembly but not a power reactor. An expected development of the nuclear program would be the addition of a nuclear power program.

With a power reactor, there will be a need for a more extensive information system for nuclear material accounting at both the state and facility levels. The number of source documents, amount of facility records, and the size of nuclear material accounting reports to the IAEA will increase, making it necessary to have more information management capabilities for the SSAC and at the facility.

\section{Basic requirements}

All relevant paragraphs of INFCIRC/153 will be in force, and the requirements of that document need to be met, as for any facilities currently under IAEA safeguards. Although the specific requirements are the same as for a minimal program, there are more aspects of nuclear material accounting and reporting that will apply with the addition of more facilities in the state. 


\section{System needs}

A new record system will be needed if the state decides to transition to power plants. It normally is not practical to adapt a system from another facility type (e.g., research reactor) as the needs may differ. When considering acquiring or developing a new facility system, the opportunity could be taken to review all systems in place for the country and to also determine if a new system at the state level would be needed.

An example of increased nuclear material accounting with a power reactor is the facility will need to calculate plutonium production, uranium consumption (burnup), and possible exchanging of pins in fuel assemblies. Additionally, there will be increased international transfers of material, requiring more activities with respect to matching the corresponding shipments and receipts.

This will likely require a state to transition from a basic accounting and reporting system (e.g., spreadsheets) to a more robust approach.

\subsection{NUCLEAR POWER PROGRAM WITHOUT OTHER FUEL CYCLE FACILITIES}

\section{Description}

A state in this category would already have several facilities under IAEA safeguards, including at least one commercial power reactor. However, there would not be any other large, bulk material nuclear facilities such as conversion and fuel fabrication plants. There may be a research facility where material unaccounted for (MUF) could occur, but that is the only expected situation where it would be present in the state.

\section{Basic requirements}

All relevant paragraphs of INFCIRC/153 will be in force, and the requirements of that document need to be met, as for all facilities currently under IAEA safeguards. The nuclear material accounting and reporting system should already be capable of meeting safeguards requirements and would need to include additional functions such as matching shipments and receipts. With a nuclear power program, additional national requirements for safeguards can be anticipated.

\section{System needs}

As information systems age, countries with a nuclear power program are faced with an important task when a new system is needed. Depending on resources, the decision may be made to acquire a commercially available information system.

\subsection{NUCLEAR POWER PROGRAM WITH OTHER FUEL CYCLE FACILITIES}

\section{Description}

These states will have many or all steps of the nuclear fuel cycle and therefore should already have an existing, well-developed system of nuclear material accounting and reporting. In addition, the staffing for both national and international safeguards will be larger than for other states. Resources may be available for development of the requisite information systems by the state. In this classification, there will be power reactors as well as facilities that process large amounts of bulk nuclear materials, where MUF is expected to occur. 


\section{Basic requirements}

States with many parts, if not all, of the nuclear fuel cycle need to have an extensive and fully featured nuclear material accountancy system. In addition to international safeguards requirements, national safeguards needs must be taken into consideration at a more developed level.

\section{System needs}

As information systems age, countries with many or all steps of the nuclear fuel cycle are faced with a significant task when a new system is needed. Depending on resources, the decision may be made to acquire a commercially available system. 


\section{THE SURVEYS}

A small team designed detailed sets of questions, or surveys, to obtain information about the functionality and capabilities of information management software system candidates available for deployment in a state. The team was composed of experts from the National Nuclear Security Administration (NNSA), US Department of Energy (DOE), and Oak Ridge National Laboratory, as well as a retired IAEA staff member. Collectively, the team represented expertise in the perspectives of the facility user, the state user, and the IAEA. This diverse composition was key to developing the survey questions because all three are stakeholders in the system. The facility inputs the data, the state reports the data, and the IAEA processes/verifies the data. The three stakeholders have very different needs for the system that states will ultimately implement.

One survey was developed for capturing information impacting the state (Appendix A) and one for capturing information relevant to a facility (Appendix B). Although there is some intentional overlap, there are specific requirements dependent upon the implementation level of a system. Surveys for both the state and the facility level included questions in the following four categories:

- General System Information

- Physical System Requirements

- Documentation

- Administration

The General System Information category includes data points such as country of origin, point of contact, number of dedicated staff supporting the software, costs, list of facilities/countries currently using the system, age of the system, etc. The Physical System Requirements category includes information such as hardware requirements, software requirements, languages implemented, user roles, and authentication. The Documentation category captures information about available system documentation, for example, requirements documents, design specification documents, user documents, etc. The final shared category is Administration. This category includes information such as the existence of change control mechanisms, transaction logs, encryption, and archive support.

There is a natural overlap on several question categories within the state and facility levels. In addition, there may be different implementations of the same function at the two levels. For example, "Nuclear Material Tracking" for a facility is relevant only for material in that installation, whereas tracking at the state level includes the matching of transfers between facilities and with other countries.

The following are categories of questions applicable to either the state or the facility. The questions within each category cover a range of activities across a nuclear program. 


\section{$\underline{\text { State Level }}$}

- System Operation and Information Flow

- Nuclear Material Accounting and Reporting

- Nuclear Material Tracking

- Source Material Reporting and Tracking (Pre-Paragraph 34(c) Material as Defined in INFCIRC/153)

- Voluntary Reporting Obligations

- Quality Assurance and Information Security

- System Relationships and Reports

- Domestic, Bilateral, and Other Requirements

\section{Facility Level}

- $\quad$ Source Data

- Supporting Documents

- Accounting Records

- IAEA Accounting Reports

- Nuclear Material Accounting

- Nuclear Material Tracking

- Source Material Reporting and Tracking (Pre-Paragraph 34(c) Material as Defined in INFCIRC/153)

- Voluntary Reporting Obligations

- Quality Assurance and Information Processing

- System Relationships and Reports

- Domestic, Bilateral, and Other Requirements 


\section{THE SYSTEMS}

Of the systems identified, the team observed live demonstrations of three, with full involvement of the developers as well as those managing the systems. These are the same systems that are readily available for distribution.

The three systems demonstrated are described below in alphabetical order. Summary tables at the end of this section provide overviews of the features and specifications of these and the other systems identified for comparison purposes. Appendix C contains additional systems, though they were not demonstrated live and therefore are not covered in the main text.

\subsection{LOCAL AREA NUCLEAR MATERIAL ACCOUNTABILITY SOFTWARE (LANMAS)}

This system was developed in 1997 and first deployed in 1998. It is designed to support basic nuclear material control and accountability recording and reporting functions required by the DOE. Implementation of Local Area Nuclear Material Accountability Software (LANMAS) provides a standardized core material accounting system and business methods in support of an overall corporate management of nuclear material accountability information. It is maintained by Savannah River Nuclear Solutions.

LANMAS is in use at about 15 DOE NNSA facilities and has an active user community. User meetings are held regularly and three levels of training are available.

It is designed for facility operator use and provides information to the US state system of accounting for and control of nuclear material, the Nuclear Materials Management and Safeguards System (NMMSS). LANMAS can also be used to capture the data elements necessary for implementation of IAEA nuclear material accounting and reporting requirements.

The system can be readily modified and therefore could be tailored to meet a large variety of facilityspecific needs. This aspect also lends itself to modifications needed for implementing IAEA safeguards requirements. However, it is a large system and may provide too much functionality for a newcomer state with a minimal nuclear program. Although it is used by many different types of US facilities with varying requirements, LANMAS is not implemented at the state level.

\subsection{NUCLEAR ACCOUNTING AND COMPLIANCE (NAC) REPORTER}

Two systems have been developed for the Nuclear Accounting and Compliance (NAC) Reporter, one specific to the United States and one more generic in design for other countries.

The US NAC Reporter was developed in 2009 to be an alternative to those nuclear material control and accounting systems usually more comprehensive than what is needed by facilities with small amounts of nuclear material and/or little activity. The system validates data in accordance with NMMSS rules and US government reporting regulations. In addition, it can assist in reconciliation of NMMSS information and distribute data to NMMSS. The system is used by some US facilities.

For implementation in other countries, NAC Reporter provides nuclear material accounting and reporting functionality at both facility and state levels. The state version of NAC Reporter is based on the reporting requirements outlined in the two format versions of Code 10 (i.e., fixed and labeled), which describe the content, format, and structure of nuclear material accounting reports to the IAEA. The software contains the core data sets and processing necessary to meet requirements for tracking nuclear material at the 
country level and providing nuclear material accounting reports to the IAEA. It was designed to accept, process, and report nuclear activities within a country.

At the facility level, the system accepts, processes, and reports nuclear material within a facility as well as tracking nuclear material. It interfaces with the state-level system and has the capability to track and report safeguards obligations on nuclear material.

NAC Reporter could provide the necessary functionality at the state and/or facility levels for both nuclear newcomer states and states with more developed nuclear programs.

\subsection{SAFEGUARDS TECHNOLOGY FOR ACCOUNTING AND REPORTING (STAR)}

Developed in 1989, Safeguards Technology for Accounting and Reporting (STAR) systems are among the first nuclear material accounting applications developed by a private company for provision to countries for use at the state and facility levels. A company in Stockholm, Sweden, AMC Konsult AB, developed all of the software and documentation since the beginning of the STAR systems. The company also provides support services and training at various levels.

The state-level application (STAR SSAC) is designed for a state to use in collecting and processing nuclear material accounting information from facilities. STAR SSAC produces nuclear material accounting reports for dispatch to the IAEA and implements safeguards functions needed by the state.

At the facility level, STAR NPP and STAR RR provide nuclear material accounting systems for use in nuclear power plants and research reactors, respectively. The systems are capable of tracking nuclear material within those types of facilities, capturing the necessary data elements for safeguards purposes, and providing nuclear material accounting information to the state-level system.

STAR systems are currently installed and operating in several countries at the state and facility levels. Compared to the other systems reviewed, there is a relatively long history of successful implementation.

Based on the history of use, STAR systems are well positioned to meet the needs of both newcomer states and states with more developed nuclear programs. For use in states with bulk nuclear material facilities such as fuel fabrication, additional product development may be needed, although bulk material accounting is already provided for in STAR RR.

\subsection{SYSTEM CAPABILITY SUMMARIES}

Tables 1 and 2 summarize the results of the surveys. The detailed completed surveys themselves contain business sensitive information and are thus not available to the public. However, a state can request additional information directly from the system suppliers. 
Table 1. State-Level Nuclear Material Accounting and Reporting System Capability Summary ${ }^{a}$

\begin{tabular}{|c|c|c|c|}
\hline \multirow{2}{*}{ Capability } & \multicolumn{3}{|c|}{ Information System } \\
\hline & LANMAS $^{b}$ & NAC Reporter & STAR \\
\hline Can report to IAEA in both Code 10 formats & & Yes & Yes \\
\hline Variable or common input format from facilities & & $\begin{array}{l}\text { Base version: one format; } \\
\text { others can be created as needed }\end{array}$ & $\begin{array}{l}\text { Yes; multiple formats can be } \\
\text { used }\end{array}$ \\
\hline $\begin{array}{l}\text { Accounting reports to the IAEA directly correspond to } \\
\text { facility records }\end{array}$ & & $\begin{array}{l}\text { Yes; depends on the facility } \\
\text { records }\end{array}$ & $\begin{array}{l}\text { Yes; for the MBR, depends on } \\
\text { the version }\end{array}$ \\
\hline Can be user tailored to meet state needs & & Yes & $\begin{array}{l}\text { To some degree, depending on } \\
\text { the version }\end{array}$ \\
\hline $\begin{array}{l}\text { Designed for facilities with discrete items, bulk material, or } \\
\text { both }\end{array}$ & & Yes & Yes \\
\hline Accounts based on IAEA material balance areas (MBAs) & & Yes & Yes \\
\hline Accounts maintained for sub-MBAs & & $\begin{array}{l}\text { No; system can be enhanced to } \\
\text { add this function }\end{array}$ & $\begin{array}{l}\text { Yes, for LOFs; can be added } \\
\text { for other MBAs as well }\end{array}$ \\
\hline Process to evaluate/close material balances & & Yes & Yes \\
\hline Material transfer tracking & & $\begin{array}{l}\text { No; can be added to meet the } \\
\text { requirement }\end{array}$ & Yes \\
\hline Source material accounting & & No; it could be added & No; it could be added \\
\hline Quality assurance/control and archiving & & Yes & Yes \\
\hline Generate reports & & Yes & Yes \\
\hline Calculates book inventories and timeliness & & $\begin{array}{l}\text { Book inventories: yes; } \\
\text { timeliness can be added }\end{array}$ & Yes \\
\hline Facility level system available & Yes & Yes & Yes \\
\hline $\begin{array}{l}\text { Number of countries where used and years in use (as of } \\
\text { October, 2013) }\end{array}$ & & $\begin{array}{l}0 \text { countries (several bids are } \\
\text { outstanding) }\end{array}$ & 3 countries, 21 years in use \\
\hline Languages used & & English & English \\
\hline
\end{tabular}

${ }^{a}$ Acronyms: IAEA = International Atomic Energy Agency, LANMAS = Local Area Nuclear Material Accountability Software, LOF = location(s) outside facility, MBA = material balance area, MBR = material balance report, NAC $=$ Nuclear Accounting and Compliance, STAR $=$ Safeguards Technology for Accounting and Reporting

${ }^{b}$ Does not have a state-level application 
Table 2. Facility-Level Nuclear Material Accounting and Reporting System Capability Summary ${ }^{a}$

\begin{tabular}{|c|c|c|c|}
\hline \multirow{2}{*}{ Capability } & \multicolumn{3}{|c|}{ Information System } \\
\hline & LANMAS & NAC Reporter & STAR (NPP and RR) \\
\hline $\begin{array}{l}\text { Includes all facility source data, supporting } \\
\text { documents, accounting/operating records }\end{array}$ & $\begin{array}{l}\text { Accounting information } \\
\text { included }\end{array}$ & $\begin{array}{l}\text { Accounting information } \\
\text { included }\end{array}$ & $\begin{array}{l}\text { Accounting information } \\
\text { included }\end{array}$ \\
\hline Maintains and prepares summary ledgers & Yes & $\begin{array}{l}\text { No, but reports can be } \\
\text { generated to meet this } \\
\text { need }\end{array}$ & Yes \\
\hline Provides information to IAEA inspectorate & Yes & $\begin{array}{l}\text { Inventory lists can be } \\
\text { prepared; ledgers need a } \\
\text { report to be generated (see } \\
\text { above) }\end{array}$ & Yes \\
\hline Reports to state level in a non-Code 10 format & Yes & Yes & Yes \\
\hline Reports to state level in both Code 10 formats & $\begin{array}{l}\text { No, but can be configured } \\
\text { to do so }\end{array}$ & Yes & Yes \\
\hline Can be user tailored to meet facility needs & $\begin{array}{l}\text { Some via parameters, } \\
\text { most by applications } \\
\text { developed for a specific } \\
\text { facility }\end{array}$ & Yes & $\begin{array}{l}\text { Yes, to some degree, } \\
\text { depending on version }\end{array}$ \\
\hline $\begin{array}{l}\text { Designed for facilities with discrete items, bulk } \\
\text { material, or both }\end{array}$ & Both & Both & $\begin{array}{l}\text { Both (STAR NPP item } \\
\text { only, STAR RR both) }\end{array}$ \\
\hline Accounts based on IAEA MBAs & Yes & $\begin{array}{l}\text { Yes, reports can be } \\
\text { generated to meet this } \\
\text { requirement }\end{array}$ & Yes \\
\hline Accounts maintained for sub-MBAs & Yes & $\begin{array}{l}\text { Yes, reports can be } \\
\text { generated to meet this } \\
\text { requirement }\end{array}$ & $\begin{array}{l}\text { In principle, yes, by } \\
\text { generating sub-MBA } \\
\text { codes }\end{array}$ \\
\hline
\end{tabular}


Table 2. Facility-Level Nuclear Material Accounting and Reporting System Capability Summary ${ }^{a}$ (continued)

\begin{tabular}{|l|l|l|l|}
\hline \multirow{2}{*}{ Capability } & \multicolumn{3}{c|}{ Information System } \\
\cline { 2 - 4 } & \multicolumn{1}{|c|}{ LANMAS } & \multicolumn{1}{c|}{ NAC Reporter } & \multicolumn{1}{c|}{ STAR (NPP and RR) } \\
\hline Process to evaluate/close material balances & $\begin{array}{l}\text { Not a standard, but has } \\
\text { feen developed for some } \\
\text { facilities }\end{array}$ & $\begin{array}{l}\text { Yes; features can be added } \\
\text { for control limits and } \\
\text { supporting inventory } \\
\text { verification }\end{array}$ & $\begin{array}{l}\text { Yes; features can be added } \\
\text { for control limits }\end{array}$ \\
\hline Material tracking of batches, items, transfers & Yes & $\begin{array}{l}\text { Partially; records on } \\
\text { combining or splitting } \\
\text { batches can be added }\end{array}$ & Yes \\
\hline Source material accounting & No; it could be added & No; it could be added & No; it could be added \\
\hline Quality assurance/quality control and archiving & $\begin{array}{l}\text { Some QA is included; } \\
\text { archiving is a facility } \\
\text { responsibility }\end{array}$ & $\begin{array}{l}\text { Some QA is included; } \\
\text { archiving is a facility } \\
\text { responsibility }\end{array}$ & Yes \\
\hline Generates reports & Yes & $\begin{array}{l}\text { Yes; are developed based } \\
\text { on facility needs }\end{array}$ & Yes \\
\hline State-level system available & No & Yes & Yes \\
\hline $\begin{array}{l}\text { Number of facilities, years in use since first } \\
\text { installation (as of October 2013) }\end{array}$ & 15 US facilities (15 years) & $\begin{array}{l}\text { 2 US facilities (4 years) } \\
\text { non-US facilities } \\
\text { (several bids are } \\
\text { outstanding) }\end{array}$ & $\begin{array}{l}8 \text { facilities (31 MBAs) in } \\
3 \text { countries (23 years) }\end{array}$ \\
\hline Languages used & & English & English, Swedish \\
\hline
\end{tabular}

${ }^{a}$ Acronyms: IAEA = International Atomic Energy Agency, LANMAS = Local Area Nuclear Material Accountability Software, MBA = material balance area, NAC $=$ Nuclear Accounting and Compliance, $\mathrm{NPP}=$ nuclear power plant, $\mathrm{QA}=$ quality assurance, $\mathrm{RR}=$ research reactor, $\mathrm{STAR}=\mathrm{Safeguards}$ Technology for Accounting and Reporting. 


\section{RECOMMENDATIONS TO POTENTIAL FUTURE USERS OF THE SYSTEMS}

When considering purchasing a system, the surveys in Appendices A and B will be a useful starting point for determining needs. Not every question is relevant to every state/facility, but these surveys are an excellent primer of considerations when writing requirements. Furthermore, receiving a live demonstration from each of the developers being considered is vital. A live demonstration helps clarify how the capabilities and features are implemented. In a few cases, the live demonstration raised questions (points of clarification) that did not arise based on the survey answers.

There are not many developers because most nations develop their own systems in house (and in their native languages). While there is a demand and real need for nuclear material accounting and reporting information systems, not that many are commercially available as the market is small.

Table 3, which only includes the systems that underwent an in-depth evaluation by the team, correlates suggested systems based on a state's status. The information in Table 3 is meant to be used as a guideline. A state should define its needs to establish requirements that can be compared to capabilities offered by the various systems and then request live demonstrations.

Table 3. Overview of Systems Based on a State's Safeguards Status ${ }^{a}$

\begin{tabular}{|l|l|l|l|l|}
\hline \multirow{2}{*}{ State safeguards status } & \multicolumn{2}{|c|}{ No existing systems } & \multicolumn{2}{c|}{ Replace current systems } \\
\cline { 2 - 5 } & \multicolumn{1}{|c|}{ State level } & \multicolumn{1}{c|}{ Facility level } & \multicolumn{1}{c|}{ State level } & \multicolumn{1}{|c|}{ Facility level } \\
\hline $\begin{array}{l}\text { Newcomer (no nuclear } \\
\text { program, e.g., SQP) }\end{array}$ & $\begin{array}{l}\text { Spreadsheets } \\
\text { (manual) }\end{array}$ & $\begin{array}{l}\text { Spreadsheets } \\
\text { (manual) }\end{array}$ & $\begin{array}{l}\text { Spreadsheets } \\
\text { (manual) }\end{array}$ & $\begin{array}{l}\text { Spreadsheets } \\
\text { (manual) }\end{array}$ \\
\hline $\begin{array}{l}\text { Newcomer (plans on a } \\
\text { minimal nuclear program) }\end{array}$ & $\begin{array}{l}\text { NAC Reporter } \\
\text { STAR } \\
\text { Spreadsheets } \\
\text { (manual) }\end{array}$ & $\begin{array}{l}\text { NAC Reporter } \\
\text { STAR } \\
\text { Spreadsheets } \\
\text { (manual) }\end{array}$ & $\begin{array}{l}\text { NAC Reporter } \\
\text { STAR }\end{array}$ & $\begin{array}{l}\text { NAC Reporter } \\
\text { STAR }\end{array}$ \\
\hline $\begin{array}{l}\text { Newcomer (plans on } \\
\text { developing the nuclear } \\
\text { program) }\end{array}$ & $\begin{array}{l}\text { NAC Reporter } \\
\text { STAR }\end{array}$ & $\begin{array}{l}\text { NAC Reporter } \\
\text { STAR }\end{array}$ & $\begin{array}{l}\text { NAC Reporter } \\
\text { STAR }\end{array}$ & $\begin{array}{l}\text { LANMAS } \\
\text { NAC Reporter } \\
\text { STAR }\end{array}$ \\
\hline $\begin{array}{l}\text { Existing (no nuclear } \\
\text { program, e.g., SQP) }\end{array}$ & $\begin{array}{l}\text { Spreadsheets } \\
\text { (manual) }\end{array}$ & $\begin{array}{l}\text { Spreadsheets } \\
\text { (manual) }\end{array}$ & $\begin{array}{l}\text { Spreadsheets } \\
\text { (manual) }\end{array}$ & $\begin{array}{l}\text { Spreadsheets } \\
\text { (manual) }\end{array}$ \\
\hline $\begin{array}{l}\text { Existing (minimal nuclear } \\
\text { program) }\end{array}$ & $\begin{array}{l}\text { NAC Reporter } \\
\text { STAR } \\
\text { Spreadsheets } \\
\text { (manual) }\end{array}$ & $\begin{array}{l}\text { NAC Reporter } \\
\text { STAR } \\
\text { Spreadsheets } \\
\text { (manual) }\end{array}$ & $\begin{array}{l}\text { NAC Reporter } \\
\text { STAR }\end{array}$ & $\begin{array}{l}\text { NAC Reporter } \\
\text { STAR }\end{array}$ \\
\hline $\begin{array}{l}\text { Existing (developed } \\
\text { nuclear program) }\end{array}$ & $\begin{array}{l}\text { NAC Reporter } \\
\text { STAR }\end{array}$ & $\begin{array}{l}\text { LANMAS } \\
\text { NAC Reporter } \\
\text { STAR }\end{array}$ & $\begin{array}{l}\text { NAC Reporter } \\
\text { STAR }\end{array}$ & $\begin{array}{l}\text { LANMAS } \\
\text { NAC Reporter } \\
\text { STAR }\end{array}$ \\
\hline
\end{tabular}

${ }^{a}$ Acronyms: LANMAS = Local Area Nuclear Material Accountability Software, NAC $=$ Nuclear Accounting and Compliance (Reporter), SQP = Small Quantities Protocol, STAR = Safeguards Technology for Accounting and Report.

${ }^{b}$ Although LANMAS would be technically viable, selecting LANMAS when setting up a new system might raise potential compatibility issues which could delay implementation. Once experience is gained, LANMAS could be used in those facilities where the features would be of most benefit. 


\section{CONCLUSION}

The study identified a number of systems that could offer the desired nuclear material accounting and reporting functionality for different levels of nuclear program implementation in states and facilities. It was determined that three of the applications could be recommended to states for consideration. The remainder of the systems were not deemed ready for inclusion based on various reasons, including availability of system information and the willingness of developers to participate.

All systems that were fully evaluated can provide a state or facility with the necessary functionality. For states with nuclear program plans that also need to build entirely new systems, NAC Reporter or STAR are recommended to begin with, to avoid possible issues of compatibility. Although LANMAS is for facility implementation only, it provides capabilities that would be of value to a state with an extensive nuclear program and could be of most benefit if a state is replacing an existing system. When replacing existing systems, consideration should be given to LANMAS, NAC Reporter, or STAR, depending on the implementation of the nuclear program in the state.

States with few or no nuclear activities, such as those with a SQP, could accomplish their requirements with manual procedures, using office-based approaches such as spreadsheets. 



\section{APPENDIX A. SURVEY: INFORMATION SYSTEM CAPABILITY ASSESSMENT STATE-LEVEL NUCLEAR MATERIAL ACCOUNTING AND REPORTING}





\section{APPENDIX A. SURVEY: INFORMATION SYSTEM CAPABILITY ASSESSMENT STATE-LEVEL NUCLEAR MATERIAL ACCOUNTING AND REPORTING}

\begin{tabular}{|c|c|}
\hline General System Information & \\
\hline 1. Information System Name & \\
\hline 2. Information System Acronym & \\
\hline 3. $\quad$ Purpose, use and scope & \\
\hline 4. Country of origin & \\
\hline 5. Administrative point of contact & \\
\hline 6. Technical point of contact & \\
\hline 7. Development organization or company & \\
\hline $\begin{array}{l}\text { 8. How long has the development organization or company been in } \\
\text { existence? }\end{array}$ & \\
\hline 9. When was the system developed? & \\
\hline 10. When was the system first deployed? & \\
\hline $\begin{array}{l}\text { 11. Is the system designed primarily for facility operator use, state } \\
\text { regulator use, or both? }\end{array}$ & \\
\hline 12. List the countries/facilities where the system is currently being used. & \\
\hline 13. How many persons currently work on upgrades and maintenance? & \\
\hline $\begin{array}{l}\text { 14. Who is responsible for maintenance and for tailoring the system to } \\
\text { meet specific state and/or facility requirements? }\end{array}$ & \\
\hline 15. Can the system be customized by the user (e.g., via tables)? & \\
\hline 16. User cost for acquiring the system & \\
\hline 17. Annual user costs for system maintenance & \\
\hline Physical System Requirements & \\
\hline 18. Describe the individual system components. & \\
\hline 19. What are the minimum recommended hardware requirements? & \\
\hline $\begin{array}{l}\text { 20. What are the minimum software requirements? Include version } \\
\text { numbers of software products. }\end{array}$ & \\
\hline 21. Is the system networked or stand-alone? & \\
\hline $\begin{array}{l}\text { 22. If networked, what are the minimum recommended networking } \\
\text { requirements? }\end{array}$ & \\
\hline $\begin{array}{l}\text { 23. Can the system accept input from various input sources (e.g., } \\
\text { manual entry, bar code reader, etc.)? }\end{array}$ & \\
\hline 24. Does the system support multiple simultaneous users? & \\
\hline 25. Are users authenticated? If so, how? & \\
\hline
\end{tabular}




\begin{tabular}{|c|c|c|}
\hline & $\begin{array}{l}\text { Are user roles and access implemented? If so, please list and } \\
\text { describe each role (e.g., high-level manager, materials manger, } \\
\text { IAEA inspection host team, read only, update) }\end{array}$ & \\
\hline 27. & Does the system employ a graphical user interface? & \\
\hline 28. & Is the system web based? & \\
\hline & What communication language (e.g., English) is used? & \\
\hline & List other languages that are supported. & \\
\hline & $\begin{array}{l}\text { If the system is client-server based, what are the functional } \\
\text { requirements for client systems? }\end{array}$ & \\
\hline 32. & $\begin{array}{l}\text { Does the system support workflow? If so, describe the workflow } \\
\text { process. }\end{array}$ & \\
\hline \multicolumn{2}{|c|}{ Documentation } & \\
\hline \multicolumn{3}{|c|}{ 33. Is a requirements specification document available? } \\
\hline \multicolumn{3}{|c|}{ 34. Is design documentation available? } \\
\hline \multicolumn{3}{|c|}{ 35. Is end-user documentation available? } \\
\hline \multicolumn{3}{|c|}{ 36. Is administration documentation available? } \\
\hline \multicolumn{3}{|c|}{ 37. As the system changes, how is documentation kept up to date? } \\
\hline \multicolumn{3}{|c|}{ Administration } \\
\hline \multicolumn{3}{|c|}{$\begin{array}{l}\text { 38. Is there a change control mechanism to document modifications, } \\
\text { upgrades, and system version? }\end{array}$} \\
\hline \multicolumn{3}{|c|}{ 39. Is there a system certification process and ongoing recertification? } \\
\hline \multicolumn{3}{|c|}{ 40. Does the system record security classification for information? } \\
\hline \multicolumn{3}{|c|}{$\begin{array}{l}\text { 41. Does the system include a transaction log? If so, describe what is } \\
\text { logged and how long entries are retained. }\end{array}$} \\
\hline \multicolumn{3}{|c|}{ 42. Does the system support archiving of data? If so, explain. } \\
\hline \multicolumn{3}{|c|}{$\begin{array}{l}\text { 43. Does the system support electronic encrypted data transfer? If so, } \\
\text { explain. }\end{array}$} \\
\hline \multicolumn{3}{|c|}{ System operation and information flow } \\
\hline \multicolumn{3}{|c|}{$\begin{array}{l}\text { 44. Can the system be operated at the facility level, sending information } \\
\text { to the state? }\end{array}$} \\
\hline & $\begin{array}{l}\text { At the state level, can changes be made to facility information or } \\
\text { must changes be made at the facility and provided to the state? }\end{array}$ & \\
\hline & $\begin{array}{l}\text { Can information from facilities/material balance areas (MBAs) be } \\
\text { received in both of the possible Code } 10 \text { formats? }\end{array}$ & \\
\hline & $\begin{array}{l}\text { Are non-Code } 10 \text { formats possible for receipt of information from } \\
\text { facilities/ MBAs? }\end{array}$ & \\
\hline
\end{tabular}




\begin{tabular}{|c|c|c|}
\hline & $\begin{array}{l}\text { Is there one format for receiving information from facilities/MBAs } \\
\text { or are multiple (tailored) formats used? }\end{array}$ & \\
\hline 49. & Is information gathering/collection at the MBA level supported? & \\
\hline 50. & $\begin{array}{l}\text { Does the system capture facility source data, supporting documents, } \\
\text { and accounting records? }\end{array}$ & \\
\hline \multicolumn{2}{|c|}{ Nuclear material accounting and reporting } & \\
\hline & Are IAEA MBAs used for nuclear material accounting? & \\
\hline & Does the system support accounting for material within sub-MBAs? & \\
\hline 53. & $\begin{array}{l}\text { Can the system maintain accounts for all nuclear materials and } \\
\text { isotopic content? }\end{array}$ & \\
\hline & $\begin{array}{l}\text { What is the level of decimal significance used for the nuclear } \\
\text { material accounts? }\end{array}$ & \\
\hline & $\begin{array}{l}\text { Is a rounding procedure implemented for accounting values, and is } \\
\text { there a specific consideration for very small amounts? }\end{array}$ & \\
\hline & $\begin{array}{l}\text { Can weight values in facility records have a different level of } \\
\text { decimal significance than in IAEA accounting reports? }\end{array}$ & \\
\hline & $\begin{array}{l}\text { Can the system account for uranium (depleted, natural, and } \\
\text { enriched) in separate accounts or in a single, combined account? }\end{array}$ & \\
\hline & $\begin{array}{l}\text { Can the system provide IAEA information in both of the possible } \\
\text { Code } 10 \text { formats? }\end{array}$ & \\
\hline 59. & $\begin{array}{l}\text { Does the system implement the Code } 10 \text { requirements of } \\
\text { report/entry numbering, including reference information for } \\
\text { additions, corrections and deletions? }\end{array}$ & \\
\hline & $\begin{array}{l}\text { Are IAEA inventory change reports based on MBA transaction } \\
\text { information? }\end{array}$ & \\
\hline 61. & $\begin{array}{l}\text { Are IAEA physical inventory listings based on MBA inventory } \\
\text { information? }\end{array}$ & \\
\hline 62. & $\begin{array}{l}\text { Are IAEA material balance reports based on MBA ledger } \\
\text { information? }\end{array}$ & \\
\hline 63. & Are records kept on exempted, terminated, and waste material? & \\
\hline & Is there a function for providing special reports to the IAEA? & \\
\hline & $\begin{array}{l}\text { Is there an accounting reconciliation function for ensuring } \\
\text { consistency with facility/MBA records and closure of material } \\
\text { balances? }\end{array}$ & \\
\hline & $\begin{array}{l}\text { Is it possible to correlate facility/MBA records with IAEA nuclear } \\
\text { material accounting reports? }\end{array}$ & \\
\hline & $\begin{array}{l}\text { Can information be retrieved based on information content, such as } \\
\text { inventory change type? }\end{array}$ & \\
\hline
\end{tabular}




\begin{tabular}{|c|c|c|}
\hline & $\begin{array}{l}\text { Can the system generate inventory reports based on MBA } \\
\text { information, as of a given date? }\end{array}$ & \\
\hline 69. & $\begin{array}{l}\text { Can the system calculate a book inventory for each MBA or state as } \\
\text { of a given date? }\end{array}$ & \\
\hline 70. & Are nuclear material inventories monitored? & \\
\hline & Are changes in inventory quantities recorded? & \\
\hline & Is a history kept of inventory quantities? & \\
\hline & Is a history of material changes for each MBA kept? & \\
\hline & Is textual information for IAEA Concise Notes captured? & \\
\hline 75. & $\begin{array}{l}\text { Are IAEA Concise Notes maintained and reported, with the relevant } \\
\text { references to MBA, report or entry? }\end{array}$ & \\
\hline \multicolumn{2}{|c|}{ Nuclear material tracking } & \\
\hline & $\begin{array}{l}\text { Is there a capability to follow domestic and international material } \\
\text { transfers? }\end{array}$ & \\
\hline & $\begin{array}{l}\text { Does the information system maintain information that relates } \\
\text { shipment and receipt records? }\end{array}$ & \\
\hline & Are advanced notifications tracked and reported? & \\
\hline \multicolumn{2}{|r|}{$\begin{array}{l}\text { Source material reporting and tracking (pre-paragraph } 34(\mathrm{c}) \\
\text { material as defined in INFCIRC/153) }\end{array}$} & \\
\hline & $\begin{array}{l}\text { Is there the provision for tracking material from mining and milling } \\
\text { through the conversion process? }\end{array}$ & \\
\hline & Are domestic and international transfers of this material tracked? & \\
\hline & $\begin{array}{l}\text { Is descriptive information captured, such as concentration and } \\
\text { intended use? }\end{array}$ & \\
\hline & $\begin{array}{l}\text { Does the system generate reports to the IAEA on the import and } \\
\text { export of source material for nuclear use? }\end{array}$ & \\
\hline \multicolumn{2}{|c|}{ Voluntary reporting obligations } & \\
\hline & Is the reporting of americium/neptunium supported? & \\
\hline & $\begin{array}{l}\text { Is it possible to account for and report trafficking incidents of } \\
\text { nuclear material and radiation sources? }\end{array}$ & \\
\hline & Is the Voluntary Reporting Scheme implemented? & \\
\hline \multicolumn{2}{|c|}{ Quality assurance and information security } & \\
\hline & $\begin{array}{l}\text { Is nuclear material information at the state level kept consistent with } \\
\text { that at the facilities? }\end{array}$ & \\
\hline & $\begin{array}{l}\text { Are there quality control/assurance steps implemented for reports } \\
\text { prior to dispatch to the IAEA? }\end{array}$ & \\
\hline
\end{tabular}




\begin{tabular}{|c|c|}
\hline $\begin{array}{l}\text { 88. Is there an accounting consistency check made between material } \\
\text { balance reports, inventory change reports, and physical inventory } \\
\text { listings? }\end{array}$ & \\
\hline $\begin{array}{l}\text { 89. Is an audit trail maintained of all corrections and how those } \\
\text { corrections relate to IAEA accounting reports? }\end{array}$ & \\
\hline $\begin{array}{l}\text { 90. Does the system provide for comparing IAEA Book Inventory } \\
\text { Statements with state information? }\end{array}$ & \\
\hline $\begin{array}{l}\text { 91. Is material tracking information available for comparing to IAEA } \\
\text { material transit statements? }\end{array}$ & \\
\hline $\begin{array}{l}\text { 92. Can the timeliness of reporting be determined for comparison with } \\
\text { IAEA timeliness statements? }\end{array}$ & \\
\hline 93. Are all records archived permanently? & \\
\hline $\begin{array}{l}\text { 94. Does the system have a mechanism for following IAEA } \\
\text { correspondence? }\end{array}$ & \\
\hline System relationships and reports & \\
\hline $\begin{array}{l}\text { 95. Does the system include Facility Attachment information as it } \\
\text { relates to nuclear material accounting and reporting? }\end{array}$ & \\
\hline $\begin{array}{l}\text { 96. Are inventory change records relationships with additional protocol } \\
\text { (AP) declarations maintained? }\end{array}$ & \\
\hline 97. Is there a system for generating reports? & \\
\hline $\begin{array}{l}\text { 98. Does the reporting system include a function for ad hoc report } \\
\text { requests? }\end{array}$ & \\
\hline 99. Can the system load historical data from previous systems? & \\
\hline $\begin{array}{l}\text { 100. Does the system generate information in an electronic format, such } \\
\text { as data files for IAEA Inspector use? }\end{array}$ & \\
\hline Domestic, bilateral, and other requirements & \\
\hline $\begin{array}{l}\text { 101. Is the system flexible enough to accommodate additional non-IAEA } \\
\text { requirements? See General System Information on tailoring the } \\
\text { system. }\end{array}$ & \\
\hline $\begin{array}{l}\text { 102. For domestic information codes not equal to IAEA codes, is there a } \\
\text { conversion function to what is required by the Agency? }\end{array}$ & \\
\hline $\begin{array}{l}\text { 103. Are material safeguards obligations (e.g., bilateral agreements), } \\
\text { ownership, and/or origin assigned and followed? }\end{array}$ & \\
\hline
\end{tabular}





\section{APPENDIX B. SURVEY: INFORMATION SYSTEM CAPABILITY ASSESSMENT FACILITY-LEVEL NUCLEAR MATERIAL ACCOUNTING AND REPORTING}





\section{APPENDIX B. SURVEY: INFORMATION SYSTEM CAPABILITY ASSESSMENT FACILITY-LEVEL NUCLEAR MATERIAL ACCOUNTING AND REPORTING}

\begin{tabular}{|c|c|}
\hline General System Information & \\
\hline 1. Information System Name & \\
\hline 2. Information System Acronym & \\
\hline 3. Purpose, use, and scope & \\
\hline 4. Country of origin & \\
\hline 5. Administrative point of contact & \\
\hline 6. Technical point of contact & \\
\hline 7. Development organization or company & \\
\hline $\begin{array}{l}\text { 8. How long has the development organization or company been in } \\
\text { existence? }\end{array}$ & \\
\hline 9. When was the system developed? & \\
\hline 10. When was the system first deployed? & \\
\hline $\begin{array}{l}\text { 11. Is the system designed primarily for facility operator use, state } \\
\text { regulator use, or both? }\end{array}$ & \\
\hline 12. List the countries/facilities where the system is currently being used. & \\
\hline 13. How many persons currently work on upgrades and maintenance? & \\
\hline $\begin{array}{l}\text { 14. Who is responsible for maintenance and for tailoring the system to } \\
\text { meet specific state and/or facility requirements? }\end{array}$ & \\
\hline 15. Can the system be customized by the user (e.g., via tables)? & \\
\hline 16. Cost of the system (purchase or lease)? & \\
\hline 17. Annual user costs for system maintenance and ongoing support & \\
\hline 18. Availability and cost of training, including updates as needed & \\
\hline 19. Can the system be sold or leased to other countries? & \\
\hline Physical System Requirements & \\
\hline 20. Describe the individual system components. & \\
\hline 21. What are the minimum recommended hardware requirements? & \\
\hline $\begin{array}{l}\text { 22. What are the minimum software requirements? Include version } \\
\text { numbers of required software products. }\end{array}$ & \\
\hline 23. Is the system networked or stand-alone? & \\
\hline $\begin{array}{l}\text { 24. If networked, what are the minimum recommended networking } \\
\text { requirements? }\end{array}$ & \\
\hline $\begin{array}{l}\text { 25. Can the system accept input from various input sources (e.g., manual } \\
\text { entry, bar code reader, etc.)? }\end{array}$ & \\
\hline
\end{tabular}




\begin{tabular}{|c|c|}
\hline \multicolumn{2}{|l|}{ 26. Does the system support multiple simultaneous users? } \\
\hline 27. Are users authenticated? If so, how? & \\
\hline $\begin{array}{l}\text { 28. Are user roles and access implemented? If so, please list and describe } \\
\text { each role. (e.g., high-level manager, materials manger, IAEA } \\
\text { inspection host team, read only, update) }\end{array}$ & \\
\hline 29. Does the system employ a graphical user interface? & \\
\hline 30. Is the system web based? & \\
\hline 31. What communication language (e.g., English) is used? & \\
\hline 32. List other languages that are supported. & \\
\hline $\begin{array}{l}\text { 33. If the system is client-server based, what are the functional } \\
\text { requirements for client systems? }\end{array}$ & \\
\hline $\begin{array}{l}\text { 34. Does the system support workflow? If so, describe the workflow } \\
\text { process. }\end{array}$ & \\
\hline Documentation & \\
\hline 35. Is a requirements specification document available? & \\
\hline 36. Is design documentation available? & \\
\hline 37. Is end-user documentation available? & \\
\hline 38. Is administration documentation available? & \\
\hline 39. As the system changes, how is documentation kept up to date? & \\
\hline Administration & \\
\hline $\begin{array}{l}\text { 40. Is there a change control mechanism to document modifications, } \\
\text { upgrades, and system version? }\end{array}$ & \\
\hline 41. Is there a system certification process and ongoing recertification? & \\
\hline 42. Does the system record security classification for information? & \\
\hline $\begin{array}{l}\text { 43. Does the system include a transaction log? If so, please describe what } \\
\text { is logged and how long entries are retained. }\end{array}$ & \\
\hline 44. Does the system support archiving of data? If so, explain. & \\
\hline $\begin{array}{l}\text { 45. Does the system support electronic encrypted data transfer? If so, } \\
\text { explain. }\end{array}$ & \\
\hline Source data & \\
\hline $\begin{array}{l}\text { 46. Is information gathering/collection at the material balance area (MBA) } \\
\text { level supported? }\end{array}$ & \\
\hline $\begin{array}{l}\text { 47. Is the system designed for facilities with discrete items, bulk material, } \\
\text { or both general types of materials? }\end{array}$ & \\
\hline $\begin{array}{l}\text { 48. Are records captured and maintained for each batch/item of material, } \\
\text { including external information, such as shipping documents? }\end{array}$ & \\
\hline
\end{tabular}


49. Does the system keep records on all changes to batch/item structures (e.g., combining, splitting, number of items in a batch)?

50. Are changes to enrichment for uranium batches/items recorded?

51. Can the system record all materials and isotopic content?

52. Are all material batch/item attributes recorded and updated, including related source documents and devices (e.g., tamper-indicating devices, seals)?

53. Are quantity data (element weights, isotope weights) and the associated measurement quality data recorded and updated?

54. Can measurement uncertainties be related to the corresponding batch/item?

55. Does the system record, update, and monitor uncertainties associated with all material on inventory?

56. Can the system generate an inventory list for a given material balance period? (also see Accounting Records section)

57. Is there a function to calculate decay (e.g., burnup of uranium in a reactor)

58. Is there a function to calculate the production of nuclear material (e.g., plutonium in a reactor)

\section{Supporting documents}

59. Can the system track changes in inventory and generate a facility inventory change document?

60. Are internal accounting area material transfers tracked and the corresponding documents prepared?

61. Is the system capable of generating reports for external transfers?

62. Does the system generate a current physical inventory item list? (Also see Nuclear Material Accounting section)

63. Can the system support custom reports?

\section{Accounting records}

64. Are general ledgers maintained for each type of material and accounting area?

65. Can a general ledger be prepared at any time, indicating the current inventory based on all information available?

66. Are subsidiary ledgers maintained for each type of material and subaccounting areas?

67. Can a subsidiary ledger be prepared at any time, indicating the current inventory based on all information available?

68. Can ledgers and subsidiary ledgers be provided in electronic format?

69. Is textual information for IAEA Concise Notes captured? 
70. Are Concise Notes maintained and reported, with the relevant reference to MBA, report or entry?

\section{IAEA accounting reports}

71. Can IAEA nuclear material accounting reports be generated in both of the possible Code 10 formats?

72. Does the system implement the Code 10 requirements of report/entry numbering, including reference information for additions, corrections and deletions?

73. How is the measurement basis and key measurement point information captured and kept updated?

74. Are IAEA inventory change reports based on inventory change documents?

75. Are IAEA material balance reports based on general ledgers?

76. Is the IAEA physical inventory listing based on the current records (list of inventory items) of identified batches in an accounting area?

77. In the event the facility does not prepare IAEA accounting reports, does the system prepare information for sending to the state?

\section{Nuclear material accounting}

78. Can the system be operated at the state level, receiving information from facilities/MBAs?

79. Does the system maintain references between all levels of records (e.g., is it possible to correlate source data, supporting documents, accounting records and IAEA reports?)

80. Can the system account for uranium (depleted, natural and enriched) in separate accounts and/or in a single, combined account (only one option is implemented in a given MBA)?

81. What is the level of decimal significance used for the nuclear material accounts?

82. Is a rounding procedure implemented for accounting values, and is there a specific consideration for very small amounts?

83. Can weight values in facility records have a different level of decimal significance than in IAEA accounting reports?

84. Are processes implemented for reconciling and closing material balances?

85. Does the system calculate control limits for SRD/ID/MUF?

86. Does the system support the taking and verification of physical inventory?

87. Are nuclear material inventories maintained and monitored?

88. Are records kept for retained waste and material exempted or terminated from safeguards? 
89. Is a history kept of inventory quantities?

90. Is a history of material changes for each MBA kept?

91. Is there a function for providing special reports to the IAEA or to the state?

\section{Nuclear material tracking}

92. Is it possible to follow a batch/item/container through the facility accounting records, including location?

93. At what detail are batches/items/containers locations tracked (e.g., to the sub-MBA level)

94. Is there a capability to follow domestic and international material transfers?

95. Does the information system maintain information that relates all shipment and receipt records?

96. Are tamper-indicating devices (e.g., seals) recorded and tracked?

97. Are transfers tracked for possible advanced notification to the IAEA?

Source material reporting and tracking (pre-paragraph 34(c) material as defined in INFCIRC/153)

98. Is there the provision for tracking material from mining and milling through the conversion process?

99. Are domestic and international transfers of this material tracked?

100. Is descriptive information captured, such as concentration and intended use?

101. If required, does the system generate reports to the state or IAEA on the import and export of source material for nuclear use?

\section{Voluntary reporting obligations}

102. Is the reporting of americium/neptunium supported?

103. Is it possible to account for and report trafficking incidents of nuclear material and radiation sources?

104. Is the Voluntary Reporting Scheme implemented?

Quality assurance and information processing

105. Are there quality control/assurance steps implemented for reports prior to dispatch to the IAEA or state?

106. Is there a consistency check made between accounting records, ledgers, and the physical inventory at the time of data entry and on demand?

107. If the facility prepares IAEA reports, is there a consistency check made between material balance reports, inventory change reports, and physical inventory listings for an MBA? 


\begin{tabular}{|l|l|}
\hline $\begin{array}{l}\text { 108. Is an audit trail maintained of all corrections and how those } \\
\text { corrections relate to IAEA accounting reports? }\end{array}$ & \\
\hline $\begin{array}{l}\text { 109. Does the system have a mechanism for following IAEA } \\
\text { correspondence related to a facility/MBA? }\end{array}$ & \\
\hline System relationships and reports & \\
\hline $\begin{array}{l}\text { 110. Does the system include Facility Attachment information as it relates } \\
\text { to nuclear material accounting and reporting? }\end{array}$ & \\
\hline $\begin{array}{l}\text { 111. Are inventory change record relationships with additional protocol } \\
\text { (AP) declarations maintained (e.g., exemptions, terminations)? }\end{array}$ & \\
\hline $\begin{array}{l}\text { 112. Is there a process to keep nuclear material information at the facility } \\
\text { consistent with that at the state level? }\end{array}$ & \\
\hline 113. Can the system load historical data from previous systems? & \\
\hline 114. Is there a system for generating reports? & \\
\hline $\begin{array}{l}\text { 115. Can information be retrieved based on information content, such as } \\
\text { inventory change type, batch identification, material type, location? }\end{array}$ & \\
\hline $\begin{array}{l}\text { 116. Does the reporting system include a function for ad hoc report } \\
\text { requests? }\end{array}$ & \\
\hline $\begin{array}{l}\text { 117. Does the system generate information in an electronic format, such as } \\
\text { data files for IAEA Inspector use? }\end{array}$ & \\
\hline Domestic, bilateral, and other requirements \\
\hline $\begin{array}{l}\text { 118. Is the system flexible enough to accommodate additional non-IAEA } \\
\text { systements? See General System Information on tailoring the }\end{array}$ & \\
\hline $\begin{array}{l}\text { 120. Are material safeguards obligations (e.g., bilateral agreements), } \\
\text { ownership, and/or origin assigned and followed? }\end{array}$ & \\
\hline
\end{tabular}


APPENDIX C. OTHER SYSTEMS 



\section{APPENDIX C. OTHER SYSTEMS}

There are existing systems that may no longer be available, are not for public release, or are not appropriate to meet a country's needs. This section provides background information on each system and serves as a directory of systems, which may or may not be available.

\section{Automated Inventory Material Accounting System (AIMAS)}

In 1998, AIMAS was developed for DOE by Argonne National Laboratory (ANL) in support of the Ukraine Nuclear Material Control and Accounting Cooperative Program. It "was not a US development project, but a US-funded collaboration with Ukraine that resulted in a system that was fully transferred to Ukraine." While "the US retains a right-to-use license," the United States has not been involved with AIMAS since some funded activities were completed in 2005. There have been no formal ties with the Ukraine AIMAS effort since then.

This is a Russian language system available at the facility level. The program is installed in three countries, though the number of facilities is unknown. It includes all facility source data, supporting documents, and accounting and operating records (although uranium accounts are considered "unified" in that enriched, deplete, and natural uranium are combined). It maintains and prepares summary ledgers, provides information to the IAEA, and is designed for facilities with both discrete items and bulk material. The program is also able to process, evaluate, and close materials balances, allow tracking of batches, items, and transfers, and generate reports.

\section{Euratom Nuclear Material Accountancy System (ENMAS)}

ENMAS is a European Union (EU) level system of nuclear material accounting and reporting. ENMAS Light is a facility-level system. The Review team exchanged correspondence with the European Atomic Energy Community (Euratom) via INSEP's regional lead in FY 2013. After reviewing the surveys (Appendices A and B) and an introduction letter, Euratom declined to participate in the project at this time. While ENMAS Light was developed only for EU members, the team has been informed that nonEU states are seeking evaluation copies of ENMAS Light from Euratom. The outcome of those efforts is not known.

\section{Facility Records and Reports Model System (FARMS)}

The team learned about FARMs from an outside source, and it is understood this is a Japanese system. However, no open source information was found; INSEP inquiries to Japan did not receive a response.

\section{MC\&A Computerized Accounting System (MCAS)}

This system was originally intended to replace a Pacific Northwest National Laboratory system for an existing system in Belarus. In 2011 a user requirements document was written with an expanded focus on tamper-indicating devices. Based on this broader scope, it was determined that MCAS was a larger system than needed by Belarus and the project was terminated.

\section{NUCMAT}

NUCMAT was designed and developed by the Armenian Nuclear Regulatory Authority with consultation from the US Nuclear Regulatory Commission and the IAEA. NUCMAT is available at the state and facility level. NUCMAT outputs reports for the IAEA (i.e., physical inventory lists, inventory change reports, and material balance reports). The facility version of NUCMAT tracks material at the material balance area and key measurement point levels and transmits data to the state version of NUCMAT. The state version also includes locations outside facilities. This system was not evaluated or demonstrated to the team as it came to light very late in the project. 


\section{$1 C$ Enterprise}

The team was informed about a Russian-developed system, 1C Enterprise, that is possibly implemented in former states of the Soviet Union. Although it is known to exist, an open source search revealed no information publically available (in English or Russian) pertaining to this nuclear material accounting software.

\section{Nuclear Materials Management and Safeguards System (NMMSS)}

NMMSS is the (national) US system "containing current and historic data on the possession, use, and shipment of nuclear materials." LANMAS (presented previously) is a facility-level system that feeds data into this national system. There are about 500 facilities sending data to NMMSS, and not all of them use LANMAS. NMMSS also outputs about 1,000 reports a month. NMMSS was not evaluated as this system would not be publically available to share. Furthermore, the system is much bigger and more complex than what the team anticipates INSEP partner states will need.

\section{Federal Information System (FIS)}

FIS is Russia's national system, modeled after the US NMMSS. This system was not explored as it was not seen as appropriate for INSEP partners, and availability is not certain. The system was developed jointly by Russian and Lawrence Livermore National Laboratory scientists. Since 2002, more than 60 Russian civilian facilities have been reporting to FIS. 